\title{
Hantavirus infection
}

Hantavirus is a genus within the family Bunyaviridae and differs from the other four genera in that family in not being transmitted by an insect vectorBunyaviruses (e.g., La Crosse) are transmitted by mosquitoes, Nairoviruses (e.g., Crimean Congo haemorrhagic fever) by ticks, Phleboviruses (e.g., Sandfly fever) by phlebotomine flies and Tospoviruses (e.g., tomato spotted wilt) by thrips. Despite this biological difference, the five genera are very similar in terms of morphology, morphogenesis, genome structure and replication strategy.

Hantaviruses are small $(95 \mathrm{~nm})$ enveloped RNA viruses with, it is presumed, a helical nucleocapsid. ${ }^{1}$ The genome is single stranded negative sense and consists of three segments, large $(c .8 \mathrm{~kb})$, medium (c. $4 \mathrm{~kb}$ ) and small $(c .2 \mathrm{~kb}){ }^{2}$ The small segment encodes two membrane glycoproteins (G1 and G2); antibodies to either G1 or G2 have been shown to neutralise virus infectivity. ${ }^{3,4}$ The large segment mRNA encodes a protein of $c .240 \mathrm{kDa}$ which has been detected in virion preparations ${ }^{5}$ and may have RNA-dependent RNA polymerase activity. ${ }^{6}$ Hantaviruses differ from most other negative strand viruses in not possessing a matrix protein. The virus replicates in the host cell cytoplasm and is assembled and released by budding into the Golgi apparatus. ${ }^{7}$ A hantavirus was first grown in artificial culture in $1981,{ }^{8}$ but primary culture is difficult. It requires not only category 3 containment facilities but also repeated blind passage for up to 3 months.

Hantavirus infections are zoonoses spread from small rodents. Various rodent populations are persistently and inapparently infected with their own hantavirus, some of which are pathogenic for man (table). Hantaviruses are classified into serotype and subtypes based upon rodent host, disease produced in man, nucleocapsid protein and membrane glycoprotein antigens, and relatedness of genomic RNA sequences. ${ }^{9,10}$ Most human infections occur in Northern and Eastern Europe, the Far East and Southwestern USA, but serosurveys have detected evidence of infection in rodents throughout the world. ${ }^{11}$

Hantaan virus causes severe haemorrhagic fever with renal syndrome (HFRS; Korean haemorrhagic fever in man) and persistent infection in the striped fieldmouse (Apodemus agrarius). The related viruses, Porogia and Fojnica, cause severe Balkan HFRS and persistent infection in the yellow-collared fieldmouse (A. flavicollis). Seoul virus causes milder HFRS, has a worldwide distribution and causes persistent infection in the Norway rat (Rattus norvegicus). Puumala virus causes mild HFRS (nephropathia epidemica) in
Northern and Eastern Europe with the bank vole (Clethrionomys glareolus) as reservoir host. In the USA, two hantaviruses, Leaky and Prospect Hill, have been detected in mice and voles but they are not known to cause disease in man. In contrast, the recently described Muerto Canyon virus (MCV) ${ }^{10}$ has been associated with the rapidly fatal hantavirus pulmonary syndrome (HPS). The virus causes persistent infection in the deer mouse (Peromyscus maniculatus). "Dade County" virus, which is similar to but distinct from MCV, also caused HPS in Florida and the reservoir host appears to be the cotton rat (Sigmodon hispidus).

Although the virus is present in the rodent in many tissues (lungs, spleen, liver, pancreas, kidney, brain and brown fat), histopathological changes do not occur and overt infection is rare. ${ }^{12}$ For example, Seoul virus infection in Norway rat populations has little or no impact on rat demographic processes. ${ }^{13}$ Once infected, the rodents excrete virus in saliva, faeces and urine for long periods, probably for life. The seroprevalence in rodent hosts varies from $3 \%$ to $15 \%{ }^{13,14}$ but in urban Norway rats in Baltimore, rates of almost $50 \%$ were recorded with a mean seroconversion rate of $22 / 100$ rats/month. ${ }^{15}$ Infection in non-rodent species, including the musk shrew (Suncus murinus), domestic and feral cats, ${ }^{16-18}$ and even dogs ${ }^{18}$ has been documented.

People become infected when they stray into the habitat of the reservoir host ${ }^{19}$ or when the host moves to areas of human habitation. ${ }^{20}$ In many cases the incidence of human infection is related to fluctuations in the reservoir host population. ${ }^{20}$ Man usually becomes infected by inhalation of dust contaminated with rodent excreta, although infection following a rodent bite has been documented. Although personto-person spread does not occur, the first demonstration that HFRS was an infectious disease was obtained by inoculation of volunteers with filtrates of patients' urine or serum. ${ }^{21}$

There are two main presentations of hantavirus infection in man-HFRS and HPS. The most severe form of HFRS occurs in Korea, China, Japan and Eastern Russia (Hantaan virus) or the Balkans (Belgrade, Porogia and Fojnica viruses). It evolves through five distinct phases. ${ }^{9}$ After an incubation period of 2-3 weeks, the clinical illness begins suddenly with influenza-like symptoms, petechiae and conjunctival haemorrhage. After 3-7 days, the hypotensive phase begins with tachycardia, vomiting, shock and further haemorrhagic signs. This lasts from $2 \mathrm{~h}$ to 3 days and is accompanied by leucocytosis and thrombocytopenia. The oliguric (or anuric) phase, 
Table. Hantaviruses: reservoirs and diseases

\begin{tabular}{llll}
\hline Disease & Virus & Geographic distribution & Reservoir host \\
\hline $\begin{array}{l}\text { Haemorrhagic fever } \\
\text { with renal syndrome }\end{array}$ & & & \\
Severe & Hantaan & Korea, China, Russia & Apodemus agrarius (sttiped fieldmouse) \\
& Porogia, Fojnica, & Balkans & Apodemus flavicollis (yellow-necked fieldmouse) \\
Moderate & Belgrade & Serbia & $?$ \\
Mild & Seoul & Worldwide & Rattus norvegicus (Norway rat) \\
Hantavirus pulmonary & Puumala & Northern and Western Europe & Clethrionomys glareolus (bank vole) \\
syndrome & Muerto Canyon & USA & Peromyscus maniculatus (deer mouse) \\
& "Dade County" & USA & Sigmodon hispidus (cotton rat) \\
& USA & ? & \\
\hline
\end{tabular}

which lasts 3-7 days, is accompanied by hypotension and severe haemorrhage (epistaxis; gastrointestinal, genitourinary and cerebral bleeding). The diuretic phase lasts from days to weeks, during which the patient may excrete $3-61$ of urine per day. The convalescent phase may last months as the patient gradually returns to full health. Most deaths occur during the oliguric phase but the high mortality $(10-15 \%)$ seen during the Korean War has fallen to $5 \%$ with appropriate management. The Balkan form is very similar but may also have pneumonic complications. ${ }^{22}$

HFRS in northern Europe is often termed nephropathia epidemica ${ }^{20}$ and is due to Puumala virus. Nephropathia epidemica presents after an incubation period of 1-8 weeks with an abrupt onset of chills and fever. Renal manifestations are common with palpable kidneys ( $30 \%$ of cases), flank pain $(66 \%)$ and polyuria $(96 \%) .{ }^{23}$ Approximately one-third of patients have haemorrhagic manifestations (epistaxis, macroscopic haematuria) but symptoms are mild with spontaneous recovery in most cases. Subclinical infection is common with one symptomatic infection to every $14-20$ cases of subclinical infection. ${ }^{20,23}$ Mortality is < $1 \%$ but a small proportion of patients may have persistent renal impairment.

Infection with Seoul virus is usually intermediate in severity between nephropathica epidemica and Hantaan HFRS. Liver impairment and damage occurs more frequently but the mortality is low (c. $1 \%) .^{9}$ There is an association between hantavirus seropositivity and patients who present with proteinuria and end-stage renal failure. ${ }^{24,25}$

In May 1993, the first cases of HPS were described in New Mexico. ${ }^{26}$ The illness presents with a sudden onset of fever, headache, myalgia and cough. It progresses rapidly with rhabdomyolysis, hypotension, thrombocytopenia and bilateral pulmonary infiltrates. Of 42 patients with HPS, $26(60 \%)$ died. ${ }^{26}$ Death

\section{References}

1. Hewlett MJ, Chiu W. Virion structure. In: Kolakofsky D (ed) Bunyaviridae. Current topics in microbiology and immunology, vol 169. Berlin, Springer-Verlag. 1991: 79-90.

2. Elliott RM, Schmaljohn CS, Collett MS. Bunyaviridae genome structure and gene expression. In: Kolakofsky D (ed) occurs within 5-14 days of onset of illness with noncardiogenic pulmonary oedema. ${ }^{27}$ Predictors of mortality include increases in haematocrit and partial thromboplastin time. The reservoir host appears to be the deer mouse (Peromyscus maniculatus) and it is noteworthy that prior to the occurrence of human cases of HPS, deer mouse populations had increased 10 -fold. the virus now named Muerto Canyon Virus (MCV), has been shown by RNA sequencing to be closely related to Prospect Hill virus. ${ }^{10}$ HPS has also been described in Louisiana and Dade County, Florida, the viruses responsible being similar to but distinct from $\mathrm{MCV}{ }^{28}$

Specific diagnosis of hantavirus infection depends upon ELISA or immunofluorescent (IF) detection of IgM or IgG antibodies to hantavirus. Antigen detection on circulating platelets, neutrophils or lymphocytes by IF can provide the diagnosis more rapidly than serological tests. ${ }^{29}$ Virus culture is not a useful diagnostic tool. Reverse transcriptasepolymerase chain reaction amplification of segments of the genome is becoming increasingly valuable in the diagnosis of hantavirus infection..$^{10.30}$

The management of HPS or HFRS is largely supportive and may involve providing ventilatory and circulatory support and renal dialysis. Ribavirin may be useful if given early in the disease. ${ }^{31}$ Prevention largely involves decreasing human contact with rodent excreta, although killed virus or subunit vaccines may be available in the future.

In the UK, serological diagnosis of hantavirus infection is available at the PHL Hantavirus Reference Laboratory, PHLS Centre for Applied Microbiology and Research, Porton Down, Wiltshire.

M. BennetT and C. A. HarT*

Departments of Veterinary Clinical Science and *Medical Microbiology and Genitourinary Medicine, University of Liverpool, PO Box 147, Liverpool L69 3BX. (Correspondence should be sent to Professor C. A. Hart).
Bunyaviridae. Current topics in microbiology and immunology, vol 169. Berlin, Springer-Verlag. 1991: 91-141.

3. Dantas JR, Okuno Y, Asada $\mathrm{H}$ et al. Characterization of glycoproteins of viruses causing hemorrhagic fever with renal syndrome (HFRS) using monoclonal antibodies. Virology 1986; 151 : 379-384. 
4. Schmaljohn CS, Chu YK, Schmaljohn AL, Dalrymple JM. Antigenic subunits of Hantaan virus expressed by baculovirus and vaccinia virus recombinants. J Virol 1990; 64: 3162-3170.

5. Elliot LH, Kiley MP, McCormick JB. Hantaan virus: identification of virion proteins. J Gen Virol 1984; 65: 1285-1293.

6. Schmaljohn CS, Dalrymple JM. Analysis of Hantaan virus RNA : evidence for a new genus of bunyaviridae. Virology 1983; 131: 482-491.

7. Matsuoka Y, Chen SY, Compans RW. Bunyavirus protein transport and assembly. In: Kolakofsky D (ed) Bunyaviridae. Current topics in microbiology and immunology, vol 169. Berlin, Springer-Verlag. 1991: 161-179.

8. French GR, Foulke RS, Brand OA, Eddy GA, Lee HW, Lee PW. Korean hemorrhagic fever: propagation of the etiologic agent in a cell line of human origin. Science 1981; 211: 1046-1048.

9. McKee KT, LeDuc JW, Peters CJ. Hantaviruses. In: Belshe RB (ed) Textbook of human virology, 2nd edn. St Louis, Mosby-Year Book. 1991: 615.

10. Nichol ST, Spiropoulou CF, Morzunov S et al. Genetic identification of a hantavirus associated with an outbreak of acute respiratory illness. Science 1993; 262: 914-917.

11. LeDuc JW, Smith GA, Childs JE et al. Global survey of antibody to Hantaan-related viruses among peridomestic rodents. Bull WHO 1986; 64: 139-144.

12. Yanagihara R, Amyx HL, Gajdusek DC. Experimental infection with Puumala virus, the etiologic agent of nephropathia epidemica, in bank voles (Clethrionomys glareolus). J Virol 1985; 55: 34-38.

13. Childs JE, Korch GW, Glass GE, LeDuc JW, Shah KV. Epizootology of Hantavirus infections in Baltimore: isolation of a virus from Norway rats, and characteristics of infected rat populations. Am J Epidemiol 1987; 126: 55-68.

14. Gavrilovskaya IN, Apekina NS, Myasnikov YA et al. Features of circulation of hemorrhagic fever with renal syndrome (HFRS) virus among small mammals in the European USSR. Arch Virol 1983; 75: 313-316.

15. Childs JE, Glass GE, Korch GW, LeDuc JW. Prospective seroepidemiology of hantaviruses and population dynamics of small mammal communities of Baltimore, Maryland. Am J Trop Med Hyg 1987; 37: 648-652.

16. Luo ZZ. Isolation of epidemic haemorrhagic fever virus from a cat. Chin J Microbiol Immunol 1985; 5: 79-81.
17. Bennett M, Lloyd G, Jones $\mathrm{N}$ et al. Prevalence of antibody in some cat populations in Britain. Vet Rec 1990; 127: 548-549.

18. Desmyter J, LeDuc JW, Johnson KM, Brasseur F, Deckers C, van Ypersele de Strihou C. Laboratory rat associated outbreak of haemorrhagic fever with renal syndrome due to Hantaan-like virus in Belgium. Lancet 1983; 2: $1445-1448$.

19. Paul JR, McClure WW. Epidemic hemorrhagic fever attack rates among United Nations troops during the Korean war. Am J Hyg 1958; 68: 126-139.

20. Niklasson B, LeDuc JW. Epidemiology of nephropathia epidemica in Sweden. $J$ Infect Dis 1987 ; 155: 269-276.

21. Kasahara S, Kitano M. Studies on the pathogen of epidemic hemorrhagic fever. Jpn J Pathol 1943; 33: 476-483.

22. Gligic A, Dimkovic N, Xiao SY et al. Belgrade virus: a new hantavirus causing severe hemorrhagic fever with renal syndrome in Yugoslavia. $J$ Infect Dis 1992; 166: 113-120.

23. Settergren B. Nephropathia epidemica (hemorrhagic fever with renal syndrome) in Scandinavia. Rev Infect Dis 1991; 13: 736-744.

24. Glass GE, Watson AJ, LeDuc JW, Kelen GD, Quinn TC, Childs JE. Infection with a ratborne hantavirus in US residents is consistently associated with hypotensive renal disease. $J$ Infect Dis 1993; 167: 614-620.

25. Peter JB, Patnaik M, Gott P, Weins B, Souw PTS. Antibodies to different strains of hantavirus in end-stage renal disease in USA and Japan. Lancet 1994; 343: 181.

26. CDC Update: Hantavirus pulmonary syndrome-United States 1993. MMWR 1993; 42: 612-614.

27. Duchin JS, Koster FT, Peters CJ et al. Hantavirus pulmonary syndrome: a clinical description of 17 patients with a newly recognized disease. New Engl J Med 1994; 330 : 949-955.

28. CDC. Newly identified hantavirus-Florida 1994. MMWR 1994; 43: 99-105.

29. Yao Z-Q, Yang W-S, Zhang W-B, Bai X-F. The distribution and duration of hantaan virus in the body fluids of patients with hemorrhagic fever with renal syndrome. $J$ Infect Dis 1989; 160: 218-224.

30. Le Guenno B. Identifying a hantavirus associated with acute respiratory illness: a PCR victory? Lancet 1993; 342: $1438-1439$.

31. Huggins JW, Hsiang CM, Cosgriff JM et al. Prospective, double-blind, concurrent, placebo-controlled clinical trial of intravenous ribavirin therapy of hemorrhagic fever with renal syndrome. J Infect Dis 1991; 164: 1119-1127. 